\begin{tabular}{|l|l|}
\hline & HHS PUbic ACCESS \\
\hline
\end{tabular}

Published in final edited form as:

Oral Surg Oral Med Oral Pathol Oral Radiol. 2017 April ; 123(4): 482-495. doi:10.1016/j.oooo. 2017.01.005.

\title{
Is it Sjögren's Syndrome or Burning Mouth Syndrome? Distinct pathoses with similar oral symptoms
}

\author{
Hawra Aljanobi, B.D.S. ${ }^{a}$, Amarpreet Sabharwal, B.D.S., MS. $^{b}$, Bralavan Krishnakumar, B.S. ${ }^{c}$, \\ and Jill M. Kramer, D.D.S., Ph.D. ${ }^{a, c}$ \\ aDepartment of Oral Diagnostics Sciences, State University of New York at Buffalo, Buffalo NY \\ bepartment of Periodontics and Endodontics, State University of New York at Buffalo, Buffalo NY \\ 'Department of Oral Biology, State University of New York at Buffalo, Buffalo NY
}

\begin{abstract}
Sjögren's Syndrome (SS) and Burning Mouth Syndrome (BMS) typically present in postmenopausal women. Although these conditions have significantly different etiopathogeneses, patients with SS or BMS often present with analogous oral complaints. The similarities between the two conditions have led to considerable confusion on the part of medical and dental practitioners, and those with BMS or SS often wait years to receive a diagnosis. Therefore, it is imperative for clinicians to understand the characteristic subjective and objective features of each disease and how these can be used to distinguish them. This review will discuss the proposed etiology, clinical manifestations, histopathology, diagnostic criteria, and patient management of SS and BMS. We also identify key differences between the two pathoses that aid in establishing the correct diagnosis. Recognition of the defining features of each condition will lead to reduced time to diagnosis and improved patient management for these poorly understood conditions.
\end{abstract}

\section{Keywords}

Sjögren's Syndrome; Burning Mouth Syndrome; Xerostomia

\section{Introduction}

Both Sjögren's Syndrome (SS) and Burning Mouth Syndrome (BMS) patients often present with similar oral complaints; however, these diseases have significantly different etiopathogeneses, diagnostic algorithms, and recommended treatments (Fig 1). SS is a chronic autoimmune disorder that has a striking female predilection, presenting most commonly in middle-age ${ }^{1}$. Primary SS (pSS) is characterized by xerophthalmia and xerostomia, and patients typically have systemic disease manifestations, as well ${ }^{2}$. Patients with secondary SS (sSS) have lacrimal and salivary dysfunction in addition to another autoimmune connective tissue disease, most commonly rheumatoid arthritis ${ }^{1,3}$. BMS is a

Corresponding Author: Dr. Jill M. Kramer, Assistant Professor, Department of Oral Biology, State University of New York at Buffalo, 3435 Main Street, 211 Foster Hall, Buffalo NY 14214, Ph: 716-829-2551, jkramer@ buffalo.edu.

Conflicts of interest: None 
chronic disorder characterized by burning sensation of the oral mucosa in the absence of any apparent clinical abnormalities. Importantly, this burning sensation is not attributable to local and/or systemic etiology 4,5 . Similar to SS, BMS affects women more commonly than men and patients may report oral dryness ${ }^{6,7}$. In contrast to SS, xerostomia is often perceived rather than actual and there are no diagnostic tests to establish the presence of BMS; thus it is a diagnosis of exclusion.

Since patients afflicted with BMS may report symptoms similar to those noted in $\mathrm{SS}^{1,7}$, failure to recognize key distinguishing factors between the two pathoses may result in considerable patient frustration and delays in diagnosis $6,8,9$. The challenges in identifying individuals with these conditions are evidenced by the fact that both SS and BMS patients typically experience symptoms for years prior to achieving a diagnosis ${ }^{10-14}$. It is essential for health care practioners to recognize key differences in these entities in order to facilitate appropriate patient management. Herein, we will review the proposed etiopathogenesis, clinical manifestations, histopathology, diagnostic criteria, and patient management of SS and BMS. We will also discuss clinical and diagnostic features that can be used to discriminate these pathoses. Improved understanding of oral manifestations of SS and BMS on the part of dental and medical professionals will facilitate accurate diagnosis and optimal care for these patients.

\section{Sjögren's Syndrome (SS)}

\section{Etiology of SS}

SS is an autoimmune disease. Although SS etiology remains poorly understood, it is characterized by exaggerated innate and adaptive immune responses that occur locally (in salivary and lacrimal tissue) and also systemically. Innate immune dysregulation is integral to SS, as salivary epithelium, dendritic cells (DCs), and macrophages contribute directly to disease ${ }^{15-19}$. The adaptive immune system is comprised of B and T cells and is also crucial to SS progression ${ }^{20}$. An increasing number of studies show a significant genetic contribution to $\mathrm{SS}^{21-23}$, and gender and environmental factors may predispose susceptible individuals to SS development ${ }^{20}$. A brief overview of the factors that contribute to SS etiology is provided.

Innate Immune Hyperactivity in SS-The contribution of the innate immune system to SS initiation and progression is well established. DCs are one of the many types of innate immune cells that infiltrate the salivary tissue in $\mathrm{SS}^{24-26}$. The plasmacytoid DC subset is a potent producer of type I interferons (IFNs); these cytokines are elevated in SS patients and mouse models and are crucial for disease development ${ }^{27-31}$. Macrophages also infiltrate the salivary gland in SS. The percentage of infiltrating macrophages correlates with disease severity and glandular enlargement ${ }^{32-34}$. Macrophages produce a wide array of proinflammatory cytokines that are implicated in SS pathogenesis including IL-18, and IL-12 $2^{18,34-36 .}$.

Salivary gland epithelial cells (SGECs) also contribute to SS. SGECs express several chemokines that promote glandular localization of $\mathrm{T}$ cells ${ }^{37-44}$. SGECs can also act as antigen presenting cells ${ }^{45-47}$. In addition, SGECs produce pro-inflammatory cytokines that are implicated in B cell pathophysiology, such as IL-6 and B-cell activating factor 
$(\mathrm{BAFF})^{43}, 44,48,49$. Thus, SGECs can directly promote chronic inflammation in SS by recruiting and activating lymphocytes as well as promoting their pathogenic function ${ }^{50-52}$.

Adaptive Immune Dysfunction in SS-T cells comprise a significant component of the lymphocytic infiltrate in exocrine glands in $\mathrm{SS}^{53}$. Alterations in normal CD4+ Thelper subset ratios are observed in SS, both within glandular tissue and systemically ${ }^{50,54-56}$. B cell dysfunction is also a hallmark of SS. Characteristic of many autoimmune diseases, B cells from SS patients secrete self-reactive antibodies ${ }^{57}$. While anti-Ro (SSA), -La (SSB), rheumatoid factor (RF), and anti-nuclear autoantibodies (ANA) are included in the SS diagnostic criteria $^{58}$, several additional autoantibodies are also well documented ${ }^{59}$. Importantly, sialadenitis is strongly associated with serum anti-Ro, -La, and RF-positivity in pSS patients ${ }^{60}$ and elevated ANA titers are detected in pSS patients even prior to the onset of symptoms ${ }^{61}$. Moreover, SS patients have a significant risk of developing B cell lymphoma ${ }^{62-70}$.

In conclusion, both innate and adaptive immune cells infiltrate the salivary glands and mediate pathology, and abnormalities are also observed in circulating immune cells in $\mathrm{SS}^{20}$. Thus, the immune system is clearly essential to SS initiation and progression.

Genetics, environment, and gender-While the factors that drive immune activation remain poorly understood, evidence suggests that genetic and environmental factors likely coalesce to influence disease development ${ }^{71}$. SS has a significant genetic component, as polymorphisms in genes related to immune function are identified in several studies ${ }^{22,72-75}$. Not surprisingly, a recent genome-wide association study (GWAS) conducted on pSS patients identified polymorphisms in genes associated with both innate and adaptive immune responses $^{21}$.

Moreover, exposure to environmental factors may predispose certain individuals to SS development. Many viruses are harbored in the salivary tissue and it is possible that these may contribute to SS. For example, cytomegalovirus (CMV), Epstein-Barr virus, and hepatitis delta virus (HDV) are identified in SS patients and both CMV and HDV cause SSlike disease in mouse models ${ }^{76-79}$. Therefore, these data suggest viral infection may be a seminal and/or sustained event that drives SS, although further studies are needed to establish this conclusively.

Finally, SS occurs most commonly in middle-aged women. While the reasons for this are unclear at present, studies suggest that sex hormones and $\mathrm{X}$ chromosome dosage may play a role in SS development. Considerable data demonstrate that while the presence of two X chromosomes is protective, it also predisposes females to numerous autoimmune diseases ${ }^{80}$. Studies show sex hormones may also contribute to SS. Ovariectomized healthy mice develop SS-like disease and Aromatase deficient mice that lack estrogen manifest a lymphoproliferative disorder that is reminiscent of $\mathrm{SS}^{81,82}$. While conclusive evidence showing that estrogen deficiency drives SS in humans is lacking, disease onset is seen most commonly in post-menopausal women, suggesting diminished estrogen production could contribute to disease development ${ }^{83}$. 


\section{Histopathology}

It is important to distinguish SS from other non-specific inflammatory conditions of the salivary tissue, such as chronic sclerosing sialadenitis ${ }^{84}$. To assess the histopathologic manifestations of SS, H\&E stained minor salivary gland tissue from the lower lip is examined ${ }^{84}$. Several specific findings are required in order for the histopathology to be consistent with SS. First, the biopsy must be adequate, having a glandular area of at least 4 $\mathrm{mm}^{2}$ and preferably between 10 and $20 \mathrm{~mm}^{2}$ to ensure representative sampling ${ }^{84}$. Next, the location and size of the lymphocytic infiltrate should be assessed. In order for the histopathologic findings to be suggestive of SS, the lymphocytic infiltrate should be perivascular or periductal and at least 50 lymphocytes (a focus) per $4 \mathrm{~mm}^{2}$ of glandular area should be present ${ }^{84,85}$. This is equivalent to one lymphocytic focus per high power field. Importantly, the acinar tissue should be intact, fibrosis should not be a salient feature, and the infiltrate should contain only a minority of plasma cells ${ }^{84}$. Of note, an abundance of plasma cells may be indicative of IgG4-related sclerosing sialadenitis rather than $\mathrm{SS}^{86}$. Finally, the number of foci should be quantified and included in the biopsy report. A minor salivary gland biopsy demonstrating features consistent with SS is shown in figure 2. It is important to point out that there is no correlation between increasing focus score and disease severity ${ }^{84}$. Accordingly, salivary foci of $\geq 1$ correlate with anti-Ro, anti-La, RF titers and ocular manifestations of disease, but greater focus scores are not indicative of more severe disease ${ }^{84}$. Finally, the presence of germinal centers should be assessed, as SS patients with germinal center formation may be more likely to develop lymphoma ${ }^{87}$.

\section{Oral Signs and Symptoms of SS}

Patients with SS may demonstrate oral disease manifestations that result primarily from salivary hypofunction, including dental caries and less commonly, burning mouth secondary to fungal infection ${ }^{88}$. Patients may also exhibit difficulty in speaking and report dysphasia and dysgeusia ${ }^{88-90}$.

Salivary hypofunction-SS patients often demonstrate reduced salivary flow ${ }^{84}$. Historically, the terminology used in studying patients with dry mouth has been inconsistent and this has led to considerable confusion in the literature. Xerostomia is a term used by some authors to describe the subjective feeling of dry mouth, while others use it to detail objective findings of salivary hypofunction. There is further debate as to what constitutes salivary hypofunction $60,91-93$. While most authors agree that unstimulated saliva production $\leq 0.2$ milliliters $/$ minute $(\mathrm{mL} / \mathrm{min}$ ) constitutes hypofunction, others suggest that true hypofunction is relative and can only be assessed by comparing flow rates over time from an individual, since "dryness" may be a subjective rather than an objective measure.

Nevertheless, many clinical studies show unstimulated levels of $\leq 0.2 \mathrm{~mL} / \mathrm{min}$ result in significant increases in caries susceptibility and oral discomfort. While the exact definition of salivary hypofunction is not well-established, the Sjögren's International Clinical Collaborative Alliance (SICCA) study designates patients with an unstimulated salivary flow rate of less than $0.1 \mathrm{~mL} / \mathrm{min}$ as having salivary hypofunction ${ }^{84}$. Interestingly, only about $70 \%$ of SS patients demonstrate xerostomia according to this definition ${ }^{84}$, so diminished saliva is seen in most, but not all, SS patients. Saliva has many important functions and 
reduced salivary production accounts for much of the oral discomfort and dental disease in SS patients.

Dental Caries-Saliva contains phosphates, bicarbonates and proteins and is an excellent buffer $^{94}$. In patients with salivary hypofunction, there is a consequent reduction in the physical cleansing from saliva. Studies show that SS patients accumulate larger amounts of cariogenic microorganisms on their dentition than individuals with normal salivary volume ${ }^{95,96}$. Patients with salivary hypofunction have carious involvement of the cervical

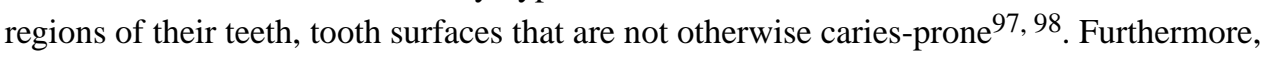
loss of teeth in SS patients resulting from dental caries and treatment visits for dental caries are higher when compared to healthy controls ${ }^{99}, 100$. Therefore, recent and extensive dental caries are consistent findings in SS patients with salivary hypofunction.

Burning Mouth—Patients with SS may describe a burning sensation of the mouth and/or the tongue ${ }^{88}$. While the source of this discomfort is not well understood, it is possible that this sensation may be related to the neurologic manifestations of SS. While sensorimotor, autonomic, cranial, and more commonly symmetric distal neuropathies are reported in the SS literature ${ }^{101-105}$, data from the SICCA study show that neurologic symptoms do not differ between SS patients and controls ${ }^{2}$. Fungal infection may represent an additional source of stomatodynia in SS. Candida colonization is reported to be higher in SS patients as compared to healthy controls ${ }^{106,107}$. Patients with candidiasis often experience a burning sensation that resolves upon clearance of the infection ${ }^{108,109}$. Thus, while oral discomfort is reported in SS, oral burning is not typically the chief complaint seen in this patient population (JMK, unpublished observations).

\section{Diagnosis of SS}

SS is challenging to diagnose and manage, and this is frustrating for both clinicians and patients alike, as many individuals struggle with symptoms of disease for many years before a definitive diagnosis is rendered ${ }^{13}$. Although new objective criteria were recently accepted by the American College of Rheumatology, the diagnosis of SS is complicated and involves the confluence of medical and dental specialties, including rheumatology, ophthalmology and oral pathology ${ }^{110}$. In order for a patient to receive a diagnosis of SS, the following criterion should be evaluated and two of the three must be present:

1. Autoantibodies: Patients must have either positive serum anti-SSA/Ro or anti$\mathrm{SSB} / \mathrm{La}$, or positive rheumatoid factor (RF) and an (anti-nuclear antibody) ANA titer $\geq 1: 320$ to fulfill this aspect of the criteria.

2. Salivary histopathology: To determine if a patient has salivary inflammation, the minor salivary gland tissue is biopsied. The tissue is evaluated for the presence of focal lymphocytic sialadenitis, and this is quantified by assigning a focus score (vide supra) $^{60}$. The focus score is the summation of the individual foci within a biopsy ${ }^{111}$. The glandular tissue must demonstrate at least one lymphocytic focus per $4 \mathrm{~mm}^{2}$ of glandular tissue in order to be consistent with the diagnosis of $\mathrm{SS}^{84}$. 
3. Ocular Dysfunction: To satisfy the ocular component of the diagnostic criteria, patients undergo testing to establish an ocular staining score (OSS $)^{58}$. These studies consist of a fluorescein test used to assess corneal dryness and lissamine green staining to evaluate the bulbar conjunctiva ${ }^{112}$. The sum of the cornea and bulbar conjunctiva scores are used to calculate the OSS and patients must have a combined score of 3 or higher to satisfy this criterion ${ }^{58,112}$.

SS Patient Management of Oral Disease Manifestations-Since SS etiology is poorly understood, there are no therapies available that target specific disease mechanisms. Accordingly, SS patients usually receive supportive treatment to manage oral complications that arise secondary to salivary dysfunction ${ }^{113}$.

Salivary hypofunction-Treatment of salivary dysfunction is challenging. While oral moistures or salivary substitutes are widely available, many patients find these to be unsatisfactory and a recent Cochrane review found that the evidence that these relieve dry mouth is relatively weak ${ }^{114}$. However, patients with salivary hypofunction should be encouraged to try these products, as some experience significant improvement in oral function with their use ${ }^{115}$. Patients may find more effective relief with parasympathomimetics, as these drugs actually restore salivary flow, although these medications are short-acting and need be taken immediately prior to mealtime ${ }^{116}$. Patients may be prescribed either pilocarpine hydrochloride or cevimeline, as both are FDA approved sialagogues ${ }^{117}$. While effective in generating saliva in most individuals, these drugs have significant untoward side effects, as they stimulate the parasympathetic nervous system indiscriminately. Therefore, patients also may experience nausea, sweating and diarrhea ${ }^{117}$. Finally, SS patients with salivary hypofunction should be encouraged to sip water frequently and use sugar-free gum or lozenges. These may help to stimulate salivary flow in patients that maintain at least some degree of salivary function ${ }^{115}$.

Caries prevention-Prevention of caries is imperative in patients that have hyposalivation, including those with SS. A panel of experts recently issued clinical practice guidelines for caries prevention in SS patients ${ }^{118}$. These guidelines are among the most comprehensive published to date and provide an excellent resource for dental professionals. The primary recommendation for preventing caries is the use of topical fluoride for all SS patients with salivary hypofunction ${ }^{118}$. These guidelines also recommend non-fluoride remineralizing agents in patients who have a high caries index ${ }^{118}$. Of note, this study found the evidence was weak regarding the role of sialagogues in caries prevention in SS.

However, the expert panel recommended that SS patients with salivary hypofunction should be encouraged to take steps to increase salivary flow (vide supra), as saliva is recognized to be crucial in maintaining a caries-free dentition ${ }^{118}$.

\section{Burning Mouth Syndrome (BMS) Etiology of BMS}

Many different pathoses cause stomatodynia and these may be either local or systemic in nature. The possible causal factors of oral burning sensation can be classified into 4 
categories: (1) local (candidiasis, benign migratory glossitis, reactions to dental materials), (2) systemic (nutritional deficiencies, hormonal disturbances, anemia, diabetes mellitus), (3) psychogenic (anxiety, depression) and (4) neurogenic factors (alterations in peripheral nerves, dopamine levels) ${ }^{119}$. The current data suggest that BMS is most appropriately classified under the fourth category. True or primary BMS is a diagnosis of exclusion and it is essential to rule out underlying oral and systemic diseases (categories 1 and 2) that cause oral burning before rendering this diagnosis ${ }^{120}$.

The etiopathogenesis of BMS remains incompletely understood, but there is a growing body of evidence demonstrating a biological basis for the neuropathies seen in BMS patients. Alterations in both the central and peripheral nervous systems of BMS patients are reported using a variety of neuro-exploratory investigations ${ }^{121,122}$. There are 3 subclasses of neurophysiologic pain described for BMS patients: peripheral small fiber neuropathy, subclinical major trigeminal neuropathy, and central pain possibly related to deficient dopaminergic inhibition ${ }^{121,123,124}$.

Small fiber neuropathy characterizes a subtype of peripheral neuropathies with impaired myelinated A $\delta$ - and unmyelinated C-fibers ${ }^{125}$. A $\delta$-fibers transmit cold sensation, while Cfibers carry heat and pain stimuli ${ }^{125}$. In BMS, trigeminal small nerve fibers demonstrate an increase in transient receptor potential vanilloid type 1 (TRPV1) and nerve growth factor (NGF) expression (vide infra) ${ }^{126}$. TRPV1 is a heat and capsaicin receptor that is regulated by NGF ${ }^{127,128}$. Both TRPV1 and NGF levels correlate with mean baseline pain scores in BMS patients, suggesting that increased receptor density could contribute to heighten pain sensation in these individuals ${ }^{126}$. In addition, purinergic $\mathrm{P} 2 \mathrm{X}$ receptors facilitate nociception in the trigeminal system and submucosal nerve fibers expressing the $\mathrm{P} 2 \mathrm{X}$ family member $\mathrm{P} 2 \mathrm{X}_{3}$ are elevated in BMS patients compared with controls (vide infra) ${ }^{129}$. Further evidence for trigeminal neuropathy is provided by studies demonstrating chorda tympani hypofunction ${ }^{130,131}$. Taken together, these studies suggest an organic basis for the small fiber neuropathy reported.

Dysfunction of the central nervous system is also implicated in BMS. A study in BMS patients found altered ratios of the striatal dopamine D1 and D2 receptors. These data suggest a decline in endogenous dopamine levels in the putamen of BMS patients ${ }^{132}$. A corroborative study found evidence for diminished dopamine in the nigrostriatal neurons of BMS patients compared with age-matched controls ${ }^{133}$. Thus, dopamine inhibition could be responsible, at least in part, for the chronic pain experienced by BMS patients ${ }^{121}$.

Finally, evidence suggests the psychogenic factors contribute to BMS. In a study of psychiatric diagnoses in patients with BMS, $49 \%$ of patients had a psychiatric diagnosis. Of these, approximately $30 \%$ suffered from an affective disorder, and an additional $30 \%$ were diagnosed with neurotic, stress-related, and somatoform disorders ${ }^{134}$. Corroborative studies report increased neuroticism, including depression and anxiety, in BMS patients ${ }^{135-137}$. Patients with BMS report that the disease onset is often followed by an acutely stressful event and that they struggle with overwhelming psychosocial discomfort ${ }^{138}$. While a mechanistic understanding of the connection between BMS and psychogenic factors is lacking, these data suggest that patients with BMS may benefit from a psychologic 
evaluation, and referral to a psychologist or psychiatrist may be warranted for individuals who suffer from personality disorders.

\section{Histopathology}

Since the diagnosis of true BMS is made in patients with clinically healthy oral mucosa, biopsy is contraindicated in these individuals, as there is no tissue that can be considered as "lesional" on clinical exam. Accordingly, studies of tongue morphology using light microscopy performed in patients with BMS and healthy control subjects found no differences in $\mathrm{H} \& \mathrm{E}$ stained tongue mucosa between the two groups ${ }^{139,}{ }^{140}$. However, immunohistochemistry performed on the tongue showed an overall reduction in the infiltrating nerve fibers in the oral mucosa of BMS patients as compared to controls, along with morphological changes indicative of axonal degeneration ${ }^{123,126,141 .}$

Studies demonstrate differences in receptor expression between BMS patients and healthy controls. The purinergic receptor $\mathrm{P}_{2} \mathrm{X}_{3}$ was significantly increased in the glossal mucosae of BMS patients as compared to control subjects ${ }^{129}$. Moreover, expression of TRPV1 and NGF in nerve fibers was higher in the tongue mucosae of BMS patients than in healthy subjects $^{126,140}$. Finally, levels of the cannabinoid receptors type 1 and 2 (CB1 and CB2), which mitigate pain and inflammation, were altered in BMS patients compared with controls ${ }^{140}$. Therefore, differences in proteins that are implicated in nociception are observed between BMS patients and controls, although it should be noted that the aforementioned studies were performed in small numbers of patients, and further work is needed to determine whether these findings have diagnostic or prognostic relevance for BMS patients. While these studies may aid in elucidating disease etiology, histologic evaluation of oral tissues is not validated for diagnosis of BMS at present ${ }^{5}$.

\section{Oral Signs and Symptoms of BMS}

As is evident by the name, patients with BMS present with a persistent burning sensation of the oral cavity. In addition, patients often report alterations in taste (dysgeusia and hypoguesia) and have perceived or actual alterations in salivary flow.

Stomatodynia-Patients with BMS often report intense burning that localizes to specific regions of the oral cavity bilaterally. While the burning sensation can manifest in any oral region, the tongue is affected most commonly. Glossodynia may occur in isolation, or may be seen in conjunction with involvement of the lips, palate, gingiva, and buccal mucosa ${ }^{9}$. A large population-based study of 169 BMS patients found $42 \%$ experienced mild pain, 28\% reported moderate pain and $13 \%$ had severe pain ${ }^{9}$. Patients typically report continuous pain that persists throughout the day ${ }^{9}$, although some studies suggest that the pain increases from morning to evening $10,142,143$. A study that examined BMS patients 5 years post-diagnosis found the pain either resolved, improve spontaneously, or remained the same, although worsening pain was reported in a minority of cases ${ }^{144}$.

Altered salivary production and composition-Xerostomia is the second most common complaint in those with BMS and is estimated to affect more than $60 \%$ of patients ${ }^{10,145}$. For many individuals, however, this dryness is perceived rather than 
actual $^{146-148}$. Interestingly, some studies show that unstimulated salivary flow is decreased in BMS patients, while stimulated flow is normal ${ }^{149-151}$. As a corollary to these studies, patients with BMS do not have a higher caries index than healthy controls, suggesting that most of these individuals maintain salivary flow that is adequate for caries prevention ${ }^{10}$.

While there are relatively few studies examining saliva from BMS patients, limited reports suggest differences in the composition of saliva from BMS patients as compared to healthy controls. A study by Lamey et al found significantly higher mean potassium, chloride and phosphorus concentrations in saliva of patients with $\mathrm{BMS}^{152}$. (This is in contrast to patients with salivary hypofunction, in which the concentration of these ions is expected to be low ${ }^{152}$ ). Analysis of the electrophoretic profile of proteins in stimulated whole saliva of patients with BMS demonstrates reduced expression of low molecular weight proteins ${ }^{119}$. In addition, salivary cytokine levels may be altered in BMS patients. Accordingly, one study showed elevation of IL-2 and IL-6 in these patients ${ }^{153}$. A second study, however, showed no difference in IL-6, IL-8, TNFa, or IL-1 $\beta$ levels ${ }^{154}$. While the reason for this discrepancy is unclear, data suggest that alterations may be seen in the salivary composition of BMS patients and this could contribute to oral discomfort. Therefore, while further work is needed to determine whether salivary composition is altered in BMS patients, most studies suggest that these individuals experience subjective xerostomia commonly.

Dysgeusia-In addition to xerostomia, patients with BMS report a variety of gustatory disturbances, including altered taste, metallic or bitter taste, and persistent taste ${ }^{9,10,146}$. Patients with BMS show significant taste disturbances as measured by taste acuity testing ${ }^{146}$. While the underlying causes of taste alterations in BMS are poorly understood, it is possible that increased activation or inhibition of certain afferent taste fibers may account for these disturbances ${ }^{10}$. In addition, changes in salivary composition in BMS patients (vide supra) may contribute to dysgeusia. The relationship between saliva and taste is well established, as taste stimulants require saliva for proper taste perception ${ }^{155}$. Thus, alterations in both taste signaling and salivary composition could lead to perceived alterations in taste in BMS patients.

\section{Diagnosis of BMS}

While there are no universally accepted criteria to define BMS, those set forth by the International Association for the Study of Pain (IASP) and those established by the International Headache Society are widely accepted. The IASP defines BMS as glossodynia or pain localized to other parts of the oral mucosa, usually bilateral and associated with dysgeusia and dry mouth. According to the IASP criteria, temporary relief following eating or drinking is almost pathognomonic of BMS ${ }^{156}$. The International Headache Society describes BMS as an intraoral burning sensation for which no medical or dental cause can be found and with the following diagnostic criteria: (1) pain in the mouth present daily and persisting for most of the day; (2) the oral mucosa is of normal appearance; and (3) local and systemic diseases have been excluded. Additionally, these criteria note that pain may be confined to the tongue and accompanying symptoms of dry mouth, taste alterations, and paresthesia are often reported ${ }^{5}$. While other criteria are also described, most of these definitions are complimentary and establish BMS as a condition in which oral pain primarily 
manifests in the tongue in the absence of objective findings ${ }^{157}$. In order to receive a diagnosis of BMS, both local and systemic conditions that can cause oral burning, including candidiasis, diabetes mellitus and vitamin deficiency, must be evaluated and ruled out ${ }^{148}$.

\section{BMS Patient Management}

While the optimal treatment for BMS remains to be established, several approaches are documented and should be considered to relieve the discomfort experienced by these patients.

Patient counseling-Many patients with BMS experience mild pain and simply need reassurance regarding the nature of their condition ${ }^{9}$. Once a diagnosis of BMS is established, patients should be informed that the disease etiology is poorly understood. It is important to emphasize that BMS is not infectious and is not transmissible by casual or intimate contact. Patients should be counseled that BMS is likely of neurologic origin and in most cases the pain will most likely remain the same or resolve spontaneously ${ }^{144}$. For patients that can tolerate their discomfort and are primarily interested in understanding their diagnosis and prognosis, no further treatment is needed.

Therapies for pain management-Studies suggest that medications that reduce the oral pain may be of benefit to patients with BMS, particularly those that characterize the pain as debilitating. Both over-the-counter and prescription medications are reported to have success in the treatment of $\mathrm{BMS}^{5}$. Alpha-lipoic acid (ALA) and capsaicin are nonprescription therapies that are cost effective and are generally well tolerated. Some studies suggest that these may relieve oral burning ${ }^{158-164}$. Several prescription medications are also administered with varying degrees of success in BMS patients. Specifically, use of clonazepam, gabapentin, tricyclic antidepressants, and serotonin-norepinephrine reuptake inhibitors is documented in BMS patients ${ }^{165-170}$. Finally, studies suggest biobehavioral (or cognitive) therapy may be beneficial to those with BMS, particularly those who are unable to tolerate medications. This therapy, which focuses on the way in which attitudes and beliefs influence behavior, may enable patients to cope with their pain more effectively ${ }^{171-174}$.

Two recent systematic reviews demonstrate that ALA, capsaicin, clonazepam, and psychotherapy may show modest benefit in the first two months following disease onset for certain disease outcomes ${ }^{175,}{ }^{176}$. However, further validation of these findings is required, as these studies have small numbers of patients, lack long-term follow-up, and have significant study variability. Further randomized control trials with follow-up of at least 12 months are indicated ${ }^{175}$. Thus, it is important to manage patient symptomology on a case-by-case basis, as currently there is no one recommended treatment regimen for BMS.

\section{Clinical similarities between SS and BMS patients}

Many oral symptoms are shared between SS and BMS patients, and this can lead to considerable delay in diagnosis and subsequent treatment. SS and BMS are seen most commonly in post-menopausal women, and both diseases are relatively rare in males $9,10,141,152,177$. In addition, SS and BMS patients frequently report symptoms of oral 
dryness $^{2,9,10}$. Finally, oral discomfort may be seen in both patient populations ${ }^{109,156,178}$. Therefore, it is difficult to distinguish SS from BMS based on patient demographics and subjective patient reporting, and further clinical evaluation and diagnostic procedures are necessary to distinguish SS from BMS (Fig. 1).

\section{Key features to distinguish SS from BMS}

It is critical to distinguish SS from BMS in order to guide patients to appropriate diagnosis and management. Several features can be used to differentiate the 2 conditions and a comprehensive oral examination and medical history are crucial in establishing the correct diagnosis. An overview of the clinical features is provided below and is summarized in Table 1.

\section{Autoantibodies}

SS, in contradistinction to BMS, is an autoimmune disease characterized by the production of self-reactive antibodies, some of which are used diagnostically. SS patients have serum autoantibodies directed against Ro, La, RF, and ANA (vide supra) ${ }^{110}$. These antibodies are present in the majority of SS patients and may be detected even prior to disease onset ${ }^{2,61}$. Patients with BMS do not experience B cell hyperactivity and do not have elevated autoantibody titers. Therefore, serological studies to determine the presence of autoantibodies are recommended to aid in distinguishing patients with SS from those with BMS.

\section{Oral Examination}

Salivary Production-It is important to perform a comprehensive oral examine in order to evaluate whether patients have actual or perceived salivary hypofunction. The floor of the mouth should be examined for pooling of saliva and the parotid and submandibular glands "milked" to assess salivary reserve ${ }^{179}$. Patients with salivary hypofunction exhibit little if any pooling of saliva in the floor of the mouth and the saliva present often has a thick, ropey quality ${ }^{117}$. (An excellent comprehensive review of the oral findings in patients with salivary hypofunction was published recently by the ADA Council on Scientific Affairs ${ }^{117}$.) In addition, the volume of unstimulated and stimulated salivary can be assessed and the production rate measured ${ }^{117}$. True unstimulated and stimulated salivary hypofunction is consistent with the diagnosis of $\mathrm{SS}^{2}$, while evidence of normal flow in individuals who report subjective feelings of xerostomia is more consistent with BMS ${ }^{146-148}$. However, it is important to be cognizant of the fact that these findings are not absolute; a minority of SS patients do not lose salivary flow and reduced unstimulated flow may be observed in BMS patients $^{2,149-151}$. As a corollary to salivary production, patients should be questioned regarding their history of dental restorations and missing teeth, with particular emphasis on recent caries. Since SS patients tend to have salivary hypofunction commonly ${ }^{2}$, these individuals are more likely to present with significant decay, missing teeth, and extensive restorative work than those with BMS.

Oral Candidiasis-A comprehensive clinical examination is important in patients who report oral burning to rule out fungal infection. Oral candidiasis has several manifestations; 
it can present as a leukoplakic area that rubs off, or the mucosa can appear atrophic and erythematous ${ }^{180}$. In addition, infection can be widespread throughout the oral cavity and also commonly occurs at the commissure region ${ }^{88}$. Candidiasis can be confirmed by cytologic smear and/or biopsy with subsequent H\&E and Periodic Acid Schiff (PAS) staining to visualize fungal hyphae ${ }^{181}$. Of note, patients that show evidence of candidiasis on clinical examination do not fulfill the BMS diagnostic criteria, as a diagnosis of BMS requires clinically normal appearing mucosa ${ }^{178}$. Therefore, evidence of candidiasis favors a diagnosis of SS rather than BMS ${ }^{109}$, although it should be noted that candidiasis may be seen in association with many different oral and systemic pathoses and is not necessarily indicative of $\mathrm{SS}^{108}$.

\section{Characteristics of oral discomfort}

The way in which patients describe their stomatodynia may aid in distinguishing SS from BMS. In SS, oral pain is most likely due to fungal infection (vide supra). Patients with candidiasis typically experience a mild burning sensation that does not change throughout the day, and the pain resolves following anti-fungal therapy ${ }^{109}$. In contrast to SS patients with stomatodynia, patients with BMS are not more prone to oral candidiasis than healthy subjects ${ }^{182}$. In BMS, the onset of pain may occur suddenly, and patients often report a specific event that they associate with the first occurrence of pain ${ }^{10}$. The pain in BMS is usually bilateral and involves the tongue predominately but may also be widespread throughout the oral cavity ${ }^{9}$. Discomfort is typically mild and persists throughout the day, although some patients experience moderate or even severe pain ${ }^{9}, 10$. While the pain may worsen as the day progresses or be intermittent, most patients experience constant pain throughout the day ${ }^{9}$. Often the anterior tongue is affected more than the posterior ${ }^{9}, 183$. Therefore, a detailed history describing the quality, quantity, and location of the oral pain can be extremely helpful in recognizing patients with BMS and distinguishing them from those with SS.

\section{Dysgeusia}

Taste disturbances tend to be seen in patients with $\mathrm{BMS}^{9,}{ }^{10}$, but are not characteristic of the majority of SS patients. Therefore, subjective reports of altered taste, such as bitter, metallic or persistent tastes are more consistent with a diagnosis of BMS than SS.

\section{Histopathology}

Commonly, patients with negative serology who report dry mouth are referred to dental professionals for minor salivary gland biopsy to establish whether the histopathological features of SS are present ${ }^{84}$. Of note, patients with negative serology may receive a diagnosis of SS if both the salivary histopathology and ocular assessments are consistent with the disease ${ }^{110}$. Therefore, patients with salivary inflammation consistent with SS should then be referred to an ophthalmologist for assessment of xerophthalmia ${ }^{110,112}$. However, a negative biopsy result in the context of negative serological studies will establish that the patient does not meet the diagnostic criteria for $\mathrm{SS}^{110}$ and such individuals should be further evaluated for BMS and other conditions that cause xerostomia if clinically indicated. 


\section{Ocular Findings}

While patients with both SS and BMS may experience subjective oral dryness ${ }^{2,10}$, patients with SS often show actual xerophthalmia. Therefore, patients who report xerophthalmia should undergo testing to distinguish perceived ocular dryness from actual ${ }^{112}$. The severity of ocular dryness of the conjunctiva and cornea is quantified using lissamine green and fluorescein dye staining, respectively. The results from both tests are compiled to yield an $\mathrm{OSS}^{112}$. The OSS is a reliable test when administered by trained ophthalmologists ${ }^{184}$. Therefore, objective assessment of ocular dryness can be helpful in distinguishing SS patients with true xerophthalmia from BMS patients with perceived ocular dryness.

\section{Conclusion}

Patients with SS or BMS present with many similarities. Therefore, it is important to perform a comprehensive medical history and oral examination on all patients who report symptoms of oral discomfort and dry mouth. Understanding the key subjective and objective differences between SS and BMS will facilitate diagnosis and result in improved patient care.

\section{References}

1. Kassan SS, Moutsopoulos HM. Clinical manifestations and early diagnosis of Sjögren syndrome. Archives of Internal Medicine. 2004; 164:1275-1284. [PubMed: 15226160]

2. Malladi AS, Sack KE, Shiboski SC, et al. Primary Sjogren's syndrome as a systemic disease: a study of participants enrolled in an international Sjogren's syndrome registry. Arthritis Care Res (Hoboken). 2012; 64:911-918. [PubMed: 22238244]

3. Fox PC. Autoimmune Diseases and Sjögren's Syndrome. Annals of the New York Academy of Sciences. 2007; 1098:15-21. [PubMed: 17332090]

4. Scala A, Checchi L, Montevecchi M, Marini I, Giamberardino MA. Update on burning mouth syndrome: overview and patient management. Crit Rev Oral Biol Med. 2003; 14:275-291. [PubMed: 12907696]

5. Crow HC, Gonzalez Y. Burning mouth syndrome. Oral and Maxillofacial Surgery Clinics of North America. 2013; 25:67-76. vi. [PubMed: 23201368]

6. Bergdahl M, Bergdahl J. Burning mouth syndrome: prevalence and associated factors. Journal of Oral Pathology \& Medicine. 1999; 28:350-354. [PubMed: 10478959]

7. Gorsky M, Silverman S Jr, Chinn H. Clinical characteristics and management outcome in the burning mouth syndrome: an open study of 130 patients. Oral surgery, Oral Medicine, Oral Pathology. 1991; 72:192-195.

8. Soares M, Chimenos-Küstner E, Subira-Pifarre C, Rodríguez dR-CM, López-López J. Association of burning mouth syndrome with xerostomia and medicines. Medicina Oral, Patología Oral y Cirugía Bucal. 2005; 10:301.

9. Kohorst JJ, Bruce AJ, Torgerson RR, Schenck LA, Davis MD. A population-based study of the incidence of burning mouth syndrome. Mayo Clinic Proceedings. 2014; 89:1545-1552. [PubMed: 25176397]

10. Grushka M. Clinical features of burning mouth syndrome. Oral Surg Oral Med Oral Pathol. 1987; 63:30-36. [PubMed: 3468464]

11. Mignogna MD, Fedele S, Lo Russo L, Leuci S, Lo Muzio L. The diagnosis of burning mouth syndrome represents a challenge for clinicians. J Orofac Pain. 2005; 19:168-173. [PubMed: 15895840]

12. Balasubramaniam R, Klasser GD, Delcanho R. Separating oral burning from burning mouth syndrome: unravelling a diagnostic enigma. Aust Dent J. 2009; 54:293-299. [PubMed: 20415926] 
13. The Sjogren's Syndrome Foundation. 2016. Web. 08 Dec. 2016 <https://www.sjogrens.org/home/ about-sjogrens/diagnosis>

14. Drage LA, Rogers RS 3rd. Clinical assessment and outcome in 70 patients with complaints of burning or sore mouth symptoms. Mayo Clinic Proceedings. 1999; 74:223-228. [PubMed: 10089989]

15. Low HZ, Witte T. Aspects of innate immunity in Sjögren's syndrome. Arthritis Res Ther. 2011; 13:218. [PubMed: 21635716]

16. Christodoulou MI, Kapsogeorgou EK, Moutsopoulos HM. Characteristics of the minor salivary gland infiltrates in Sjögren's syndrome. J Autoimmun. 2010; 34:400-407. [PubMed: 19889514]

17. Zhou D, Chen YT, Chen F, et al. Critical Involvement of Macrophage Infiltration in the Development of Sjögren's Syndrome-Associated Dry Eye. Am J Pathol. 2012; 181:753-760. [PubMed: 22770665]

18. Sakai A, Sugawara Y, Kuroishi T, Sasano T, Sugawara S. Identification of IL-18 and Th17 cells in salivary glands of patients with Sjögren's syndrome, and amplification of IL-17-mediated secretion of inflammatory cytokines from salivary gland cells by IL-18. J Immunol. 2008; 181:2898-2906. [PubMed: 18684981]

19. Okuma A, Hoshino K, Ohba T, et al. Enhanced Apoptosis by Disruption of the STAT3-IxB- $\zeta$ Signaling Pathway in Epithelial Cells Induces Sjögren's Syndrome-like Autoimmune Disease. Immunity. 2013

20. Mavragani CP, Moutsopoulos HM. Sjogren's syndrome. Annual Review of Pathology. 2014; 9:273-285.

21. Lessard CJ, Li H, Adrianto I, et al. Variants at multiple loci implicated in both innate and adaptive immune responses are associated with Sjogren's syndrome. Nat Genet. 2013; 45:1284-1292. [PubMed: 24097067]

22. Ice JA, Li H, Adrianto I, et al. Genetics of Sjögren's syndrome in the genome-wide association era. J Autoimmun. 2012

23. Segal BM, Nazmul-Hossain AN, Patel K, Hughes P, Moser KL, Rhodus NL. Genetics and genomics of Sjögren's syndrome: research provides clues to pathogenesis and novel therapies. Oral Surg Oral Med Oral Pathol Oral Radiol Endod. 2011; 111:673-680. [PubMed: 21497524]

24. Vogelsang P, Brun JG, Oijordsbakken G, Skarstein K, Jonsson R, Appel S. Levels of plasmacytoid dendritic cells and type-2 myeloid dendritic cells are reduced in peripheral blood of patients with primary Sjogren's syndrome. Annals of the Rheumatic Diseases. 2010; 69:1235-1238. [PubMed: 19914903]

25. Ozaki Y, Ito T, Son Y, et al. Decrease of blood dendritic cells and increase of tissue-infiltrating dendritic cells are involved in the induction of Sjögren's syndrome but not in the maintenance. Clinical and Experimental Immunology. 2010; 159:315-326. [PubMed: 20015272]

26. Vogelsang P, Jonsson MV, Dalvin ST, Appel S. Role of Dendritic Cells in Sjögren's Syndrome. Scandinavian journal of immunology. 2006; 64:219-226. [PubMed: 16918690]

27. Gottenberg JE, Cagnard N, Lucchesi C, et al. Activation of IFN pathways and plasmacytoid dendritic cell recruitment in target organs of primary Sjogren's syndrome. Proceedings of the National Academy of Sciences of the United States of America. 2006; 103:2770-2775. [PubMed: 16477017]

28. Båve U, Nordmark G, Lövgren T, et al. Activation of the type I interferon system in primary Sjögren's syndrome: A possible etiopathogenic mechanism. Arthritis \& Rheumatism. 2005; 52:1185-1195. [PubMed: 15818675]

29. Siegal FP, Kadowaki N, Shodell M, et al. The nature of the principal type 1 interferon-producing cells in human blood. Science (New York, N.Y.). 1999; 284:1835-1837.

30. Ronnblom L, Alm GV. A pivotal role for the natural interferon alpha-producing cells (plasmacytoid dendritic cells) in the pathogenesis of lupus. J Exp Med. 2001; 194:F59-63. [PubMed: 11748288]

31. Borden EC, Sen GC, Uze G, et al. Interferons at age 50: past, current and future impact on biomedicine. Nature Reviews. Drug Discovery. 2007; 6:975-990. [PubMed: 18049472]

32. Zhou D, McNamara NA. Macrophages: important players in primary Sjogren's syndrome? Expert Review of Clinical Immunology. 2014; 10:513-520. [PubMed: 24646086] 
33. Christodoulou MI, Kapsogeorgou EK, Moutsopoulos HM. Characteristics of the minor salivary gland infiltrates in Sjögren's syndrome. Journal of Autoimmunity. 2010; 34:400-407. [PubMed: 19889514]

34. Manoussakis MN, Boiu S, Korkolopoulou P, et al. Rates of infiltration by macrophages and dendritic cells and expression of interleukin-18 and interleukin-12 in the chronic inflammatory lesions of Sjogren's syndrome: correlation with certain features of immune hyperactivity and factors associated with high risk of lymphoma development. Arthritis Rheum. 2007; 56:39773988. [PubMed: 18050195]

35. Chen YT, Lazarev S, Bahrami AF, et al. Interleukin-1 receptor mediates the interplay between CD4+ T cells and ocular resident cells to promote keratinizing squamous metaplasia in Sjogren's syndrome. Lab Invest. 2012; 92:556-570. [PubMed: 22231738]

36. Chen YT, Nikulina K, Lazarev S, et al. Interleukin-1 as a phenotypic immunomodulator in keratinizing squamous metaplasia of the ocular surface in Sjogren's syndrome. Am J Pathol. 2010; 177:1333-1343. [PubMed: 20696775]

37. Xanthou G, Polihronis M, Tzioufas AG, Paikos S, Sideras P, Moutsopoulos HM. "Lymphoid" chemokine messenger RNA expression by epithelial cells in the chronic inflammatory lesion of the salivary glands of Sjogren's syndrome patients: possible participation in lymphoid structure formation. Arthritis and Rheumatism. 2001; 44:408-418. [PubMed: 11229473]

38. Salomonsson S, Jonsson MV, Skarstein K, et al. Cellular basis of ectopic germinal center formation and autoantibody production in the target organ of patients with Sjogren's syndrome. Arthritis and Rheumatism. 2003; 48:3187-3201. [PubMed: 14613282]

39. Ogawa N, Ping L, Zhenjun L, Takada Y, Sugai S. Involvement of the interferon-gamma-induced T cell-attracting chemokines, interferon-gamma-inducible 10-kd protein (CXCL10) and monokine induced by interferon-gamma (CXCL9), in the salivary gland lesions of patients with Sjogren's syndrome. Arthritis and Rheumatism. 2002; 46:2730-2741. [PubMed: 12384933]

40. Amft N, Curnow SJ, Scheel-Toellner D, et al. Ectopic expression of the B cell-attracting chemokine BCA-1 (CXCL13) on endothelial cells and within lymphoid follicles contributes to the establishment of germinal center-like structures in Sjogren's syndrome. Arthritis and Rheumatism. 2001; 44:2633-2641. [PubMed: 11710719]

41. Amft N, Bowman SJ. Chemokines and cell trafficking in Sjogren's syndrome. Scandinavian Journal of Immunology. 2001; 54:62-69. [PubMed: 11439149]

42. Cuello C, Palladinetti P, Tedla N, et al. Chemokine expression and leucocyte infiltration in Sjogren's syndrome. British Journal of Rheumatology. 1998; 37:779-783. [PubMed: 9714357]

43. Bombardieri M, Barone F, Pittoni V, et al. Increased circulating levels and salivary gland expression of interleukin-18 in patients with Sjogren's syndrome: relationship with autoantibody production and lymphoid organization of the periductal inflammatory infiltrate. Arthritis Research \& Therapy. 2004; 6:R447-456. [PubMed: 15380044]

44. Horiuchi M, Yamano S, Inoue H, et al. Possible involvement of IL-12 expression by Epstein-Barr virus in Sjogren syndrome. J Clin Pathol. 1999; 52:833-837. [PubMed: 10690174]

45. Matsumura R, Umemiya K, Goto T, et al. Glandular and extraglandular expression of costimulatory molecules in patients with Sjogren's syndrome. Annals of the Rheumatic Diseases. 2001; 60:473-482. [PubMed: 11302869]

46. Manoussakis MN, Dimitriou ID, Kapsogeorgou EK, et al. Expression of B7 costimulatory molecules by salivary gland epithelial cells in patients with Sjogren's syndrome. Arthritis and Rheumatism. 1999; 42:229-239. [PubMed: 10025916]

47. Moutsopoulos HM, Hooks JJ, Chan CC, Dalavanga YA, Skopouli FN, Detrick B. HLA-DR expression by labial minor salivary gland tissues in Sjogren's syndrome. Annals of the Rheumatic Diseases. 1986; 45:677-683. [PubMed: 3527087]

48. Boumba D, Skopouli FN, Moutsopoulos HM. Cytokine mRNA expression in the labial salivary gland tissues from patients with primary Sjogren's syndrome. Br J Rheumatol. 1995; 34:326-333. [PubMed: 7788146]

49. Fox RI, Kang HI, Ando D, Abrams J, Pisa E. Cytokine mRNA expression in salivary gland biopsies of Sjogren's syndrome. Journal of Immunology (Baltimore Md. : 1950). 1994; 152:55325539. 
50. Mitsias DI, Tzioufas AG, Veiopoulou C, et al. The Th1/Th2 cytokine balance changes with the progress of the immunopathological lesion of Sjogren's syndrome. Clin Exp Immunol. 2002; 128:562-568. [PubMed: 12067313]

51. Moutsopoulos HM. Sjogren's syndrome: autoimmune epithelitis. Clin Immunol Immunopathol. 1994; 72:162-165. [PubMed: 8050187]

52. Manoussakis MN, Kapsogeorgou EK. The role of epithelial cells in the pathogenesis of Sjogren's syndrome. Clinical Reviews in Allergy \& Immunology. 2007; 32:225-230. [PubMed: 17992589]

53. Singh N, Cohen PL. The T cell in Sjogren's syndrome: force majeure, not spectateur. J Autoimmun. 2012; 39:229-233. [PubMed: 22709856]

54. van Woerkom JM, Kruize AA, Wenting-van Wijk MJ, et al. Salivary gland and peripheral blood T helper 1 and 2 cell activity in Sjogren's syndrome compared with non-Sjogren's sicca syndrome. Ann Rheum Dis. 2005; 64:1474-1479. [PubMed: 15817659]

55. Szodoray P, Gal I, Barath S, et al. Immunological alterations in newly diagnosed primary Sjogren's syndrome characterized by skewed peripheral T-cell subsets and inflammatory cytokines. Scand J Rheumatol. 2008; 37:205-212. [PubMed: 18465456]

56. Garcic-Carrasco M, Font J, Filella X, et al. Circulating levels of Th1/Th2 cytokines in patients with primary Sjogren's syndrome: correlation with clinical and immunological features. Clin Exp Rheumatol. 2001; 19:411-415. [PubMed: 11491496]

57. Tzioufas AG, Tatouli IP, Moutsopoulos HM. Autoantibodies in Sjögren's syndrome: Clinical presentation and regulatory mechanisms. Presse Med. 2012

58. Shiboski SC, Shiboski CH, Criswell L, et al. American College of Rheumatology classification criteria for Sjögren's syndrome: a data-driven, expert consensus approach in the Sjögren's International Collaborative Clinical Alliance cohort. Arthritis Care Res (Hoboken). 2012; 64:475487. [PubMed: 22563590]

59. Fayyaz A, Kurien BT, Scofield RH. Autoantibodies in Sjogren's Syndrome. Rheum Dis Clin North Am. 2016; 42:419-434. [PubMed: 27431345]

60. Daniels TE, Cox D, Shiboski CH, et al. Associations between salivary gland histopathologic diagnoses and phenotypic features of Sjögren's syndrome among 1,726 registry participants. Arthritis Rheum. 2011; 63:2021-2030. [PubMed: 21480190]

61. Jonsson R, Theander E, Sjöström B, Brokstad K, Henriksson G. Autoantibodies present before symptom onset in primary Sjögren syndrome. JAMA. 2013; 310:1854-1855. [PubMed: 24193084]

62. Bendaoud B, Pennec YL, Lelong A, et al. IgA-containing immune complexes in the circulation of patients with primary Sjogren's syndrome. Journal of Autoimmunity. 1991; 4:177-184. [PubMed: 2031660]

63. Youinou P, Devauchelle-Pensec V, Pers JO. Significance of B cells and B cell clonality in Sjogren's syndrome. Arthritis and Rheumatism. 2010; 62:2605-2610. [PubMed: 20496425]

64. Fox RI. Sjogren's syndrome. Lancet (London, England). 2005; 366:321-331.

65. Zintzaras E, Voulgarelis M, Moutsopoulos HM. The risk of lymphoma development in autoimmune diseases: a meta-analysis. Archives of Internal Medicine. 2005; 165:2337-2344. [PubMed: 16287762]

66. Scofield RH, Farris AD, Horsfall AC, Harley JB. Fine specificity of the autoimmune response to the Ro/SSA and La/SSB ribonucleoproteins. Arthritis \& Rheumatism. 1999; 42:199-209. [PubMed: 10025913]

67. Slobbe RL, Pruijn GJ, Van Venrooij WJ. Ro (SS-A) and La (SS-B) ribonucleoprotein complexes: structure, function and antigenicity. Annales de Medecine Interne. 1991; 142:592-600. [PubMed: 1725476]

68. Theander E, Henriksson G, Ljungberg O, Mandl T, Manthorpe R, Jacobsson LTH. Lymphoma and other malignancies in primary Sjögren's syndrome: A cohort study on cancer incidence and lymphoma predictors. Annals of the Rheumatic Diseases. 2006; 65:796-803. [PubMed: 16284097]

69. Hansen A, Lipsky PE, Dorner T. B-cell lymphoproliferation in chronic inflammatory rheumatic diseases. Nature clinical practice. Rheumatology. 2007; 3:561-569.

70. Theander E, Vasaitis L, Baecklund E, et al. Lymphoid organisation in labial salivary gland biopsies is a possible predictor for the development of malignant lymphoma in primary Sjogren's syndrome. Annals of the Rheumatic Diseases. 2011; 70:1363-1368. [PubMed: 21715359] 
71. Mavragani CP, Moutsopoulos HM. Sjögren's Syndrome. Annual Review of Pathology: Mechanisms of Disease. 2014; 9:273-285.

72. Korman B, Alba M, Le J, et al. Variant form of STAT4 is associated with primary Sjögren's syndrome. Genes and Immunity. 2008; 9:267-270. [PubMed: 18273036]

73. Bolstad AI, Wargelius A, Nakken B, Haga H-J, Jonsson R. Fas and Fas ligand gene polymorphisms in primary Sjogren's syndrome. The Journal of Rheumatology. 2000; 27:2397-2405. [PubMed: 11036836]

74. Miceli-Richard C, Comets E, Loiseau P, Puechal X, Hachulla E, Mariette X. Association of an IRF5 gene functional polymorphism with Sjögren's syndrome. Arthritis \& Rheumatism. 2007; 56:3989-3994. [PubMed: 18050197]

75. Nossent JC, Lester S, Zahra D, Mackay C, Rischmueller M. Polymorphism in the $5^{\prime}$ regulatory region of the B-lymphocyte activating factor gene is associated with the Ro/La autoantibody response and serum BAFF levels in primary Sjögren's syndrome. Rheumatology. 2008; 47:13111316. [PubMed: 18617551]

76. Weller ML, Gardener MR, Bogus ZC, et al. Hepatitis Delta Virus Detected in Salivary Glands of Sjogren's Syndrome Patients and Recapitulates a Sjogren's Syndrome-Like Phenotype in Vivo. Pathog Immun. 2016; 1:12-40. [PubMed: 27294212]

77. Wen S, Shimizu N, Yoshiyama H, Mizugaki Y, Shinozaki F, Takada K. Association of Epstein-Barr virus (EBV) with Sjogren's syndrome: differential EBV expression between epithelial cells and lymphocytes in salivary glands. Am J Pathol. 1996; 149:1511-1517. [PubMed: 8909241]

78. Kivity S, Arango MT, Ehrenfeld M, et al. Infection and autoimmunity in Sjogren's syndrome: a clinical study and comprehensive review. J Autoimmun. 2014; 51:17-22. [PubMed: 24637076]

79. Ohyama Y, Carroll VA, Deshmukh U, Gaskin F, Brown MG, Fu SM. Severe focal sialadenitis and dacryoadenitis in NZM2328 mice induced by MCMV: a novel model for human Sjogren's syndrome. J Immunol. 2006; 177:7391-7397. [PubMed: 17082658]

80. Libert C, Dejager L, Pinheiro I. The X chromosome in immune functions: when a chromosome makes the difference. Nat Rev Immunol. 2010; 10:594-604. [PubMed: 20651746]

81. Ishimaru N, Arakaki R, Watanabe M, Kobayashi M, Miyazaki K, Hayashi Y. Development of autoimmune exocrinopathy resembling Sjogren's syndrome in estrogen-deficient mice of healthy background. Am J Pathol. 2003; 163:1481-1490. [PubMed: 14507655]

82. Shim GJ, Warner M, Kim HJ, et al. Aromatase-deficient mice spontaneously develop a lymphoproliferative autoimmune disease resembling Sjogren's syndrome. Proc Natl Acad Sci U S A. 2004; 101:12628-12633. [PubMed: 15314222]

83. Bouma HR, Bootsma H, van Nimwegen JF, et al. Aging and Immunopathology in Primary Sjogren's Syndrome. Curr Aging Sci. 2015; 8:202-213. [PubMed: 26212053]

84. Daniels TE, Cox D, Shiboski CH, et al. Associations between salivary gland histopathologic diagnoses and phenotypic features of Sjögren's syndrome among 1,726 registry participants. Arthritis \& Rheumatism. 2011; 63:2021-2030. [PubMed: 21480190]

85. Vitali C, Bombardieri S, Jonsson R, et al. Classification criteria for Sjögren's syndrome: a revised version of the European criteria proposed by the American-European Consensus Group. Ann Rheum Dis. 2002; 61:554-558. [PubMed: 12006334]

86. Geyer JT, Ferry JA, Harris NL, et al. Chronic sclerosing sialadenitis (Kuttner tumor) is an IgG4associated disease. Am J Surg Pathol. 2010; 34:202-210. [PubMed: 20061932]

87. Theander E, Vasaitis L, Baecklund E, et al. Lymphoid organisation in labial salivary gland biopsies is a possible predictor for the development of malignant lymphoma in primary Sjögren's syndrome. Ann Rheum Dis. 2011; 70:1363-1368. [PubMed: 21715359]

88. Napenas JJ, Rouleau TS. Oral complications of Sjogren's syndrome. Oral and Maxillofacial Surgery Clinics of North America. 2014; 26:55-62. [PubMed: 24287193]

89. Lopez-Pintor RM, Fernandez Castro M, Hernandez G. Oral involvement in patients with primary Sjogren's syndrome. Multidisciplinary care by dentists and rheumatologists. Reumatol Clin. 2015; 11:387-394. [PubMed: 26022574]

90. Rhodus NL, Colby S, Moller K, Bereuter J. Quantitative assessment of dysphagia in patients with primary and secondary Sjogren's syndrome. Oral Surg Oral Med Oral Pathol Oral Radiol Endod. 1995; 79:305-310. [PubMed: 7621008] 
91. Papas A, Russell D, Singh M, Kent R, Triol C, Winston A. Caries clinical trial of a remineralising toothpaste in radiation patients. Gerodontology. 2008; 25:76-88. [PubMed: 18485139]

92. Banting DW, Papas A, Clark DC, Proskin HM, Schultz M, Perry R. The effectiveness of 10\% chlorhexidine varnish treatment on dental caries incidence in adults with dry mouth. Gerodontology. 2000; 17:67-76. [PubMed: 11808057]

93. Navazesh M, Christensen C, Brightman V. Clinical criteria for the diagnosis of salivary gland hypofunction. J Dent Res. 1992; 71:1363-1369. [PubMed: 1629451]

94. Bardow A, Moe D, Nyvad B, Nauntofte B. The buffer capacity and buffer systems of human whole saliva measured without loss of $\mathrm{CO}_{2}$. Archives of Oral Biology. 2000; 45:1-12. [PubMed: 10669087]

95. Leung K, Leung W, McMillan A. Supra-gingival microbiota in Sjögren's syndrome. Clinical Oral Investigations. 2007; 11:415-423. [PubMed: 17609998]

96. Pedersen AM, Bardow A, Nauntofte B. Salivary changes and dental caries as potential oral markers of autoimmune salivary gland dysfunction in primary Sjogren's syndrome. BMC Clin Pathol. 2005; 5:4. [PubMed: 15740617]

97. Mathews S, Kurien B, Scofield R. Oral manifestations of Sjögren's syndrome. Journal of Dental Research. 2008; 87:308-318. [PubMed: 18362310]

98. Soto-Rojas AE, Kraus A. The oral side of Sjögren syndrome. Diagnosis and treatment. A review. Archives of Medical Research. 2002; 33:95-106. [PubMed: 11886706]

99. Bøge Christensen L, Petersen PE, Thorn JJ, Schiødt M. Dental caries and dental health behavior of patients with primary Sjogren syndrome. Acta Odontologica. 2001; 59:116-120.

100. Fox PC, Bowman SJ, Segal B, et al. Oral involvement in primary Sjögren syndrome. The Journal of the American Dental Association. 2008; 139:1592-1601. [PubMed: 19047665]

101. Mellgren SI, Conn DL, Stevens JC, Dyck PJ. Peripheral neuropathy in primary Sjögren's syndrome. Neurology. 1989; 39:390-390. [PubMed: 2538774]

102. Gøransson LG, Herigstad A, Tjensvoll AB, Harboe E, Mellgren SI, Omdal R. Peripheral neuropathy in primary Sjögren syndrome: a population-based study. Archives of Neurology. 2006; 63:1612-1615. [PubMed: 17101831]

103. Delalande S, De Seze J, Fauchais A-L, et al. Neurologic manifestations in primary Sjogren syndrome: a study of 82 patients. Medicine. 2004; 83:280-291. [PubMed: 15342972]

104. Mori K, Iijima M, Koike H, et al. The wide spectrum of clinical manifestations in Sjögren's syndrome-associated neuropathy. Brain. 2005; 128:2518-2534. [PubMed: 16049042]

105. Pavlakis PP, Alexopoulos H, Kosmidis ML, et al. Peripheral neuropathies in Sjogren's syndrome: a critical update on clinical features and pathogenetic mechanisms. J Autoimmun. 2012; 39:2733. [PubMed: 22318209]

106. Rhodus NL, Bloomquist C, Liljemark W, Bereuter J. Prevalence, density, and manifestations of oral Candida albicans in patients with Sjogren's syndrome. J Otolaryngol. 1997; 26:300-305. [PubMed: 9343767]

107. Torres SR, Peixoto CB, Caldas DM, et al. Relationship between salivary flow rates and Candida counts in subjects with xerostomia. Oral Surg Oral Med Oral Pathol Oral Radiol Endod. 2002; 93:149-154. [PubMed: 11862202]

108. Lalla RV, Patton LL, Dongari-Bagtzoglou A. Oral candidiasis: pathogenesis, clinical presentation, diagnosis and treatment strategies. J Calif Dent Assoc. 2013; 41:263-268. [PubMed: 23705242]

109. Guinn AC, Rouleau TS, Brennan MT. Burning tongue and lips. Diagnosis: Sjogren syndrome with concurrent candidal infection. J Am Dent Assoc. 2010; 141:541-545. [PubMed: 20436101]

110. Shiboski S, Shiboski C, Criswell L, et al. American College of Rheumatology classification criteria for Sjögren's syndrome: A data-driven, expert consensus approach in the Sjögren's International Collaborative Clinical Alliance Cohort. Arthritis Care \& Research. 2012; 64:475487. [PubMed: 22563590]

111. Daniels TE, Cox D, Shiboski CH, et al. Associations between salivary gland histopathologic diagnoses and phenotypic features of Sjogren's syndrome among 1,726 registry participants. Arthritis and Rheumatism. 2011; 63:2021-2030. [PubMed: 21480190] 
112. Whitcher JP, Shiboski CH, Shiboski SC, et al. A simplified quantitative method for assessing keratoconjunctivitis sicca from the Sjogren's Syndrome International Registry. Am J Ophthalmol. 2010; 149:405-415. [PubMed: 20035924]

113. Mavragani CP, Nezos A, Moutsopoulos HM. New advances in the classification, pathogenesis and treatment of Sjogren's syndrome. Current Opinion in Rheumatology. 2013; 25:623-629. [PubMed: 23846338]

114. Furness S, Worthington HV, Bryan G, Birchenough S, McMillan R. Interventions for the management of dry mouth: topical therapies. Cochrane Database Syst Rev. 2011:CD008934. [PubMed: 22161442]

115. Kramer JM. Current concepts in Sjogren's syndrome and considerations for the dental practitioner. The New York State Dental Journal. 2015; 81:24-29.

116. Fox RI, Konttinen Y, Fisher A. Use of muscarinic agonists in the treatment of Sjogren's syndrome. Clin Immunol. 2001; 101:249-263. [PubMed: 11726216]

117. Plemons JM, Al-Hashimi I, Marek CL. American Dental Association Council on Scientific A. Managing xerostomia and salivary gland hypofunction: executive summary of a report from the American Dental Association Council on Scientific Affairs. J Am Dent Assoc. 2014; 145:867873. [PubMed: 25082939]

118. Zero DT, Brennan MT, Daniels TE, et al. Clinical practice guidelines for oral management of Sjogren disease: Dental caries prevention. J Am Dent Assoc. 2016; 147:295-305. [PubMed: 26762707]

119. de Moura SA, de Sousa JM, Lima DF, Negreiros AN, Silva Fde V, da Costa LJ. Burning mouth syndrome (BMS): sialometric and sialochemical analysis and salivary protein profile. Gerodontology. 2007; 24:173-176. [PubMed: 17696895]

120. Nasri-Heir C, Zagury JG, Thomas D, Ananthan S. Burning mouth syndrome: Current concepts. J Indian Prosthodont Soc. 2015; 15:300-307. [PubMed: 26929531]

121. Jaaskelainen SK. Pathophysiology of primary burning mouth syndrome. Clin Neurophysiol. 2012; 123:71-77. [PubMed: 22030140]

122. Shinozaki T, Imamura Y, Kohashi R, et al. Spatial and Temporal Brain Responses to Noxious Heat Thermal Stimuli in Burning Mouth Syndrome. J Dent Res. 2016

123. Lauria G, Majorana A, Borgna M, et al. Trigeminal small-fiber sensory neuropathy causes burning mouth syndrome. Pain. 2005; 115:332-337. [PubMed: 15911160]

124. Puhakka A, Forssell H, Soinila S, et al. Peripheral nervous system involvement in primary burning mouth syndrome-results of a pilot study. Oral Dis. 2016; 22:338-344. [PubMed: 26847146]

125. Lauria G. Small fibre neuropathies. Curr Opin Neurol. 2005; 18:591-597. [PubMed: 16155446]

126. Yilmaz Z, Renton T, Yiangou Y, et al. Burning mouth syndrome as a trigeminal small fibre neuropathy: Increased heat and capsaicin receptor TRPV1 in nerve fibres correlates with pain score. J Clin Neurosci. 2007; 14:864-871. [PubMed: 17582772]

127. Elokely K, Velisetty P, Delemotte L, et al. Understanding TRPV1 activation by ligands: Insights from the binding modes of capsaicin and resiniferatoxin. Proc Natl Acad Sci U S A. 2016; 113:E137-145. [PubMed: 26719417]

128. Eskander MA, Ruparel S, Green DP, et al. Persistent Nociception Triggered by Nerve Growth Factor (NGF) Is Mediated by TRPV1 and Oxidative Mechanisms. J Neurosci. 2015; 35:85938603. [PubMed: 26041925]

129. Beneng K, Yilmaz Z, Yiangou Y, McParland H, Anand P, Renton T. Sensory purinergic receptor $\mathrm{P} 2 \mathrm{X} 3$ is elevated in burning mouth syndrome. International Journal of Oral and Maxillofacial Surgery. 2010; 39:815-819. [PubMed: 20418063]

130. Eliav E, Kamran B, Schaham R, Czerninski R, Gracely RH, Benoliel R. Evidence of chorda tympani dysfunction in patients with burning mouth syndrome. J Am Dent Assoc. 2007; 138:628-633. [PubMed: 17473041]

131. Nasri-Heir C, Gomes J, Heir GM, et al. The role of sensory input of the chorda tympani nerve and the number of fungiform papillae in burning mouth syndrome. Oral Surg Oral Med Oral Pathol Oral Radiol Endod. 2011; 112:65-72. [PubMed: 21601494] 
132. Hagelberg N, Forssell H, Rinne JO, et al. Striatal dopamine D1 and D2 receptors in burning mouth syndrome. Pain. 2003; 101:149-154. [PubMed: 12507709]

133. Jaaskelainen SK, Rinne JO, Forssell H, et al. Role of the dopaminergic system in chronic pain -- a fluorodopa-PET study. Pain. 2001; 90:257-260. [PubMed: 11207397]

134. Takenoshita M, Sato T, Kato Y, et al. Psychiatric diagnoses in patients with burning mouth syndrome and atypical odontalgia referred from psychiatric to dental facilities. Neuropsychiatr Dis Treat. 2010; 6:699-705. [PubMed: 21127687]

135. Al Quran FA. Psychological profile in burning mouth syndrome. Oral Surg Oral Med Oral Pathol Oral Radiol Endod. 2004; 97:339-344. [PubMed: 15024358]

136. Rojo L, Silvestre FJ, Bagan JV, De Vicente T. Prevalence of psychopathology in burning mouth syndrome. A comparative study among patients with and without psychiatric disorders and controls. Oral Surg Oral Med Oral Pathol. 1994; 78:312-316. [PubMed: 7970590]

137. Rojo L, Silvestre FJ, Bagan JV, De Vicente T. Psychiatric morbidity in burning mouth syndrome. Psychiatric interview versus depression and anxiety scales. Oral Surg Oral Med Oral Pathol. 1993; 75:308-311. [PubMed: 8469540]

138. Hakeberg M, Hallberg LR, Berggren U. Burning mouth syndrome: experiences from the perspective of female patients. European Journal of Oral Sciences. 2003; 111:305-311. [PubMed: 12887395]

139. Sardella A, Gualerzi A, Lodi G, Sforza C, Carrassi A, Donetti E. Morphological evaluation of tongue mucosa in burning mouth syndrome. Archives of Oral Biology. 2012; 57:94-101. [PubMed: 21824605]

140. Borsani E, Majorana A, Cocchi MA, et al. Epithelial expression of vanilloid and cannabinoid receptors: a potential role in burning mouth syndrome pathogenesis. Histol Histopathol. 2014; 29:523-533. [PubMed: 24190005]

141. Penza P, Majorana A, Lombardi R, et al. "Burning tongue" and "burning tip": the diagnostic challenge of the burning mouth syndrome. Clin J Pain. 2010; 26:528-532. [PubMed: 20551728]

142. Lopez-Jornet P, Molino Pagan D, Andujar Mateos P, Rodriguez Agudo C, Pons-Fuster A. Circadian rhythms variation of pain in burning mouth syndrome. Geriatr Gerontol Int. 2015; 15:490-495. [PubMed: 25155230]

143. Braud A, Toure B, Agbo-Godeau S, Descroix V, Boucher Y. Characteristics of pain assessed with visual analog scale and questionnaire in burning mouth syndrome patients: a pilot study. J Orofac Pain. 2013; 27:235-242. [PubMed: 23882456]

144. Sardella A, Lodi G, Demarosi F, Bez C, Cassano S, Carrassi A. Burning mouth syndrome: a retrospective study investigating spontaneous remission and response to treatments. Oral Dis. 2006; 12:152-155. [PubMed: 16476036]

145. Silvestre-Rangil J, Silvestre FJ, Tamarit-Santafe C, Bautista D. Burning mouth syndrome: correlation of treatment to clinical variables of the disease. Med Oral Patol Oral Cir Bucal. 2011; 16:e890-894. [PubMed: 21743413]

146. Hershkovich O, Nagler RM. Biochemical analysis of saliva and taste acuity evaluation in patients with burning mouth syndrome, xerostomia and/or gustatory disturbances. Archives of Oral Biology. 2004; 49:515-522. [PubMed: 15126133]

147. Granot M, Nagler RM. Association between regional idiopathic neuropathy and salivary involvement as the possible mechanism for oral sensory complaints. J Pain. 2005; 6:581-587. [PubMed: 16139777]

148. Minor JS, Epstein JB. Burning mouth syndrome and secondary oral burning. Otolaryngol Clin North Am. 2011; 44:205-219. vii. [PubMed: 21093630]

149. Lee YC, Hong IK, Na SY, Eun YG. Evaluation of salivary function in patients with burning mouth syndrome. Oral Dis. 2015; 21:308-313. [PubMed: 24962264]

150. Poon R, Su N, Ching V, Darling M, Grushka M. Reduction in unstimulated salivary flow rate in burning mouth syndrome. Br Dent J. 2014; 217:E14. [PubMed: 25303607]

151. Spadari F, Venesia P, Azzi L, et al. Low basal salivary flow and burning mouth syndrome: new evidence in this enigmatic pathology. J Oral Pathol Med. 2015; 44:229-233. [PubMed: 25155153] 
152. Lamey PJ, Lamb AB. Prospective study of aetiological factors in burning mouth syndrome. British Medical Journal. 1988; 296:1243-1246. [PubMed: 3133028]

153. Simcic D, Pezelj-Ribaric S, Grzic R, Horvat J, Brumini G, Muhvic-Urek M. Detection of salivary interleukin 2 and interleukin 6 in patients with burning mouth syndrome. Mediators Inflamm. 2006; 2006:54632. [PubMed: 16864905]

154. Suh KI, Kim YK, Kho HS. Salivary levels of IL-1beta, IL-6, IL-8, and TNF-alpha in patients with burning mouth syndrome. Archives of Oral Biology. 2009; 54:797-802. [PubMed: 19555923]

155. Matsuo R. Role of saliva in the maintenance of taste sensitivity. Crit Rev Oral Biol Med. 2000; 11:216-229. [PubMed: 12002816]

156. Task Force on Taxonomy of the International Association for the Study of Pain. Classification of Chronic Pain: Descriptions of Chronic Pain Syndromes and Definitions of Pain Terms. 2. Seattle: IASP Press; 1994.

157. Thoppay JR, De Rossi SS, Ciarrocca KN. Burning mouth syndrome. Dental Clinics of North America. 2013; 57:497-512. [PubMed: 23809306]

158. Petruzzi M, Lauritano D, De Benedittis M, Baldoni M, Serpico R. Systemic capsaicin for burning mouth syndrome: short-term results of a pilot study. J Oral Pathol Med. 2004; 33:111-114. [PubMed: 14720197]

159. Silvestre FJ, Silvestre-Rangil J, Tamarit-Santafe C, Bautista D. Application of a capsaicin rinse in the treatment of burning mouth syndrome. Med Oral Patol Oral Cir Bucal. 2012; 17:e1-4. [PubMed: 21743415]

160. Marino R, Torretta S, Capaccio P, Pignataro L, Spadari F. Different therapeutic strategies for burning mouth syndrome: preliminary data. J Oral Pathol Med. 2010; 39:611-616. [PubMed: 20701667]

161. Lopez-D'alessandro E, Escovich L. Combination of alpha lipoic acid and gabapentin, its efficacy in the treatment of Burning Mouth Syndrome: a randomized, double-blind, placebo controlled trial. Med Oral Patol Oral Cir Bucal. 2011; 16:e635-640. [PubMed: 20711135]

162. Femiano F. Burning mouth syndrome (BMS): an open trial of comparative efficacy of alpha-lipoic acid (thioctic acid) with other therapies. Minerva Stomatologica. 2002; 51:405-409. [PubMed: 12473978]

163. Femiano F, Gombos F, Scully C, Busciolano M, De Luca P. Burning mouth syndrome (BMS): controlled open trial of the efficacy of alpha-lipoic acid (thioctic acid) on symptomatology. Oral Dis. 2000; 6:274-277. [PubMed: 11002408]

164. Femiano F, Scully C. Burning mouth syndrome (BMS): double blind controlled study of alphalipoic acid (thioctic acid) therapy. J Oral Pathol Med. 2002; 31:267-269. [PubMed: 12110042]

165. Heckmann SM, Kirchner E, Grushka M, Wichmann MG, Hummel T. A double-blind study on clonazepam in patients with burning mouth syndrome. Laryngoscope. 2012; 122:813-816. [PubMed: 22344742]

166. Gremeau-Richard C, Woda A, Navez ML, et al. Topical clonazepam in stomatodynia: a randomised placebo-controlled study. Pain. 2004; 108:51-57. [PubMed: 15109507]

167. White TL, Kent PF, Kurtz DB, Emko P. Effectiveness of gabapentin for treatment of burning mouth syndrome. Arch Otolaryngol Head Neck Surg. 2004; 130:786-788. [PubMed: 15210564]

168. Heckmann SM, Heckmann JG, Ungethum A, Hujoel P, Hummel T. Gabapentin has little or no effect in the treatment of burning mouth syndrome - results of an open-label pilot study. Eur J Neurol. 2006; 13:e6-7.

169. Pinto A, Sollecito TP, DeRossi SS. Burning mouth syndrome. A retrospective analysis of clinical characteristics and treatment outcomes. The New York State Dental Journal. 2003; 69:18-24.

170. Mignogna MD, Adamo D, Schiavone V, Ravel MG, Fortuna G. Burning mouth syndrome responsive to duloxetine: a case report. Pain Med. 2011; 12:466-469. [PubMed: 21223496]

171. Patton LL, Siegel MA, Benoliel R, De Laat A. Management of burning mouth syndrome: systematic review and management recommendations. Oral Surg Oral Med Oral Pathol Oral Radiol Endod. 2007; 103(Suppl:S39):e31-13.

172. Bergdahl J, Anneroth G, Perris H. Cognitive therapy in the treatment of patients with resistant burning mouth syndrome: a controlled study. J Oral Pathol Med. 1995; 24:213-215. [PubMed: 7616460] 
173. Femiano F, Gombos F, Scully C. Burning Mouth Syndrome: open trial of psychotherapy alone, medication with alpha-lipoic acid (thioctic acid), and combination therapy. Med Oral. 2004; 9:813. [PubMed: 14704612]

174. Miziara ID, Filho BC, Oliveira R, Rodrigues dos Santos RM. Group psychotherapy: an additional approach to burning mouth syndrome. J Psychosom Res. 2009; 67:443-448. [PubMed: 19837207]

175. de Moraes M, do Amaral Bezerra BA, da Rocha Neto PC, de Oliveira Soares AC, Pinto LP, de Lisboa Lopes Costa A. Randomized trials for the treatment of burning mouth syndrome: an evidence-based review of the literature. J Oral Pathol Med. 2012; 41:281-287. [PubMed: 22092585]

176. Kisely S, Forbes M, Sawyer E, Black E, Lalloo R. A systematic review of randomized trials for the treatment of burning mouth syndrome. J Psychosom Res. 2016; 86:39-46. [PubMed: 27302545]

177. Helmick CG, Felson DT, Lawrence RC, et al. Estimates of the prevalence of arthritis and other rheumatic conditions in the United States. Part I. Arthritis Rheum. 2008; 58:15-25. [PubMed: 18163481]

178. Headache Classification Committee of the International Headache Society. The International Classification of Headache Disorders, 3rd edition (beta version). Cephalalgia. 2013; 33:629-808. [PubMed: 23771276]

179. Wu, A. Patient Education Sheet How To Massage Salivary Glands. 2016. Web. 08 Dec. 2016. <https://www.sjogrens.org/files/brochures/Salivary_Glands_Massage.pdf>

180. Stoopler ET, Sollecito TP. Oral mucosal diseases: evaluation and management. Med Clin North Am. 2014; 98:1323-1352. [PubMed: 25443679]

181. Millsop JW, Fazel N. Oral candidiasis. Clin Dermatol. 2016; 34:487-494. [PubMed: 27343964]

182. Sardella A, Lodi G, Demarosi F, Uglietti D, Carrassi A. Causative or precipitating aspects of burning mouth syndrome: a case-control study. J Oral Pathol Med. 2006; 35:466-471. [PubMed: 16918597]

183. Savage NW, Boras VV, Barker K. Burning mouth syndrome: clinical presentation, diagnosis and treatment. Australas J Dermatol. 2006; 47:77-81. quiz 82-73. [PubMed: 16637799]

184. Rose-Nussbaumer J, Lietman TM, Shiboski CH, et al. Inter-grader Agreement of the Ocular Staining Score in the Sjogren's International Clinical Collaborative Alliance (SICCA) Registry. American Journal of Ophthalmology. 2015; 160:1150-1153. e1153. [PubMed: 26302236] 


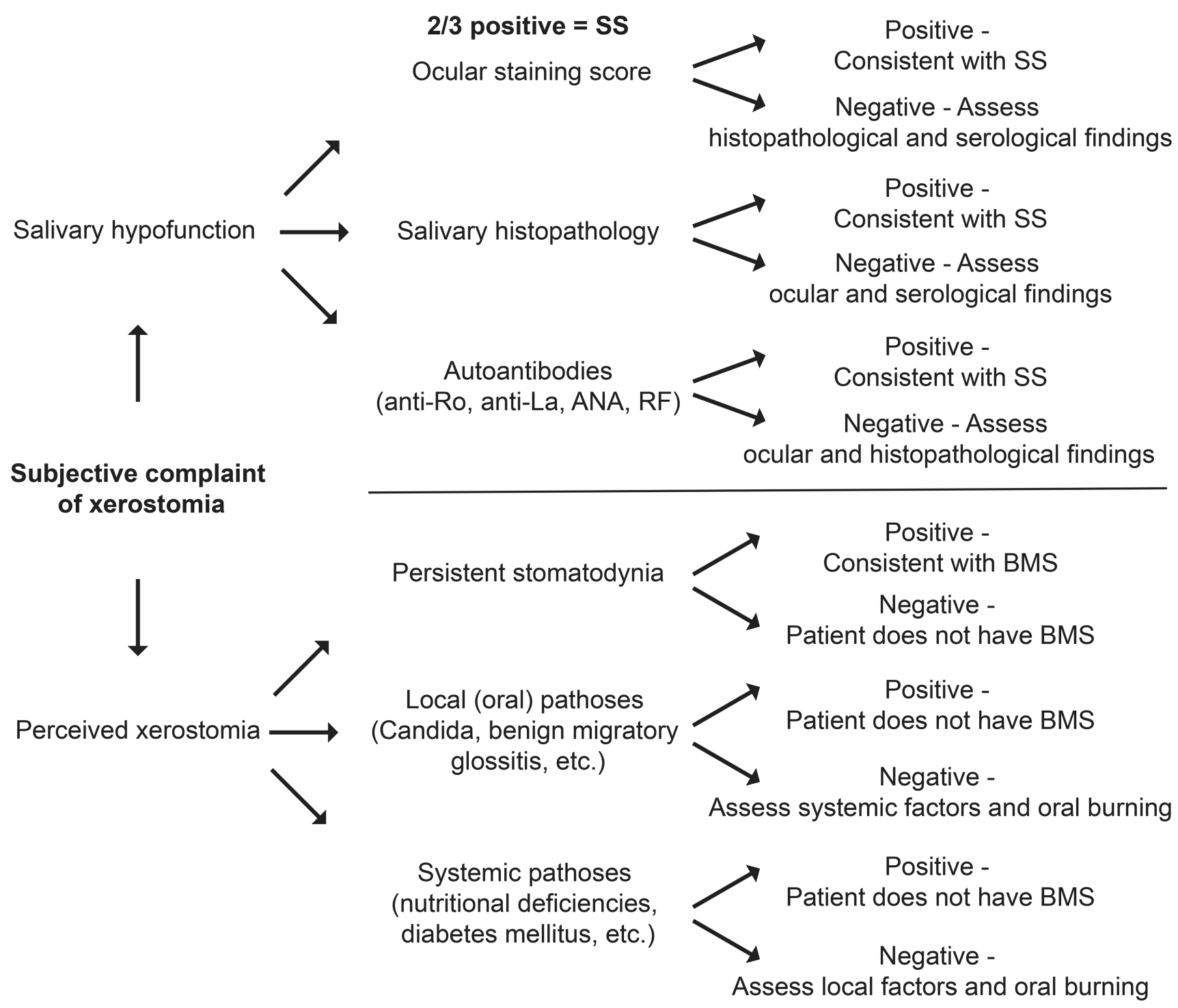

Fig. 1. Clinical algorithm to aid in distinguishing SS from BMS 


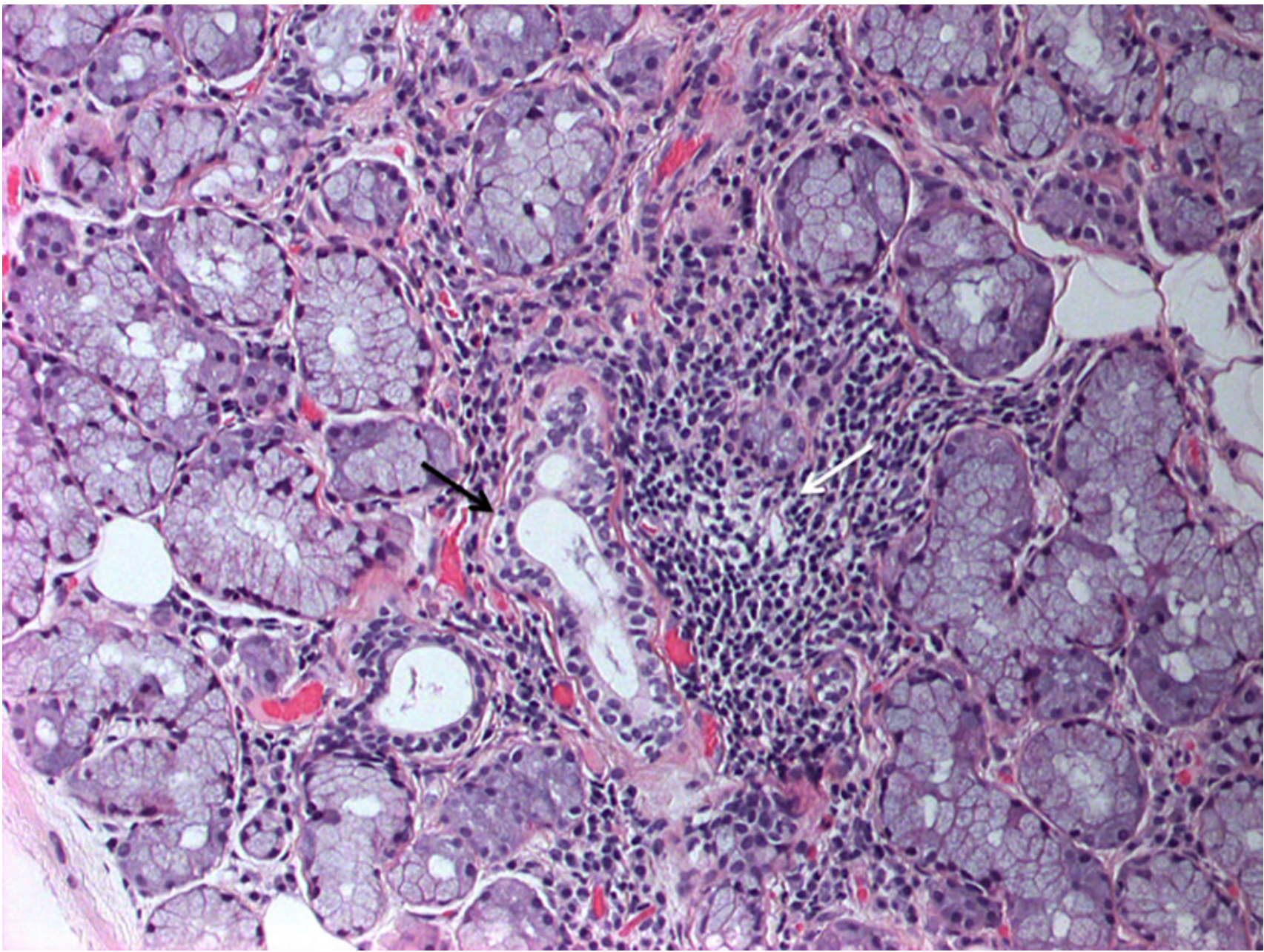

Fig. 2. Focal lymphocytic sialadenitis consistent with SS

H\&E stained minor salivary gland biopsy from a patient diagnosed with SS. The black arrow indicates a salivary gland duct and the white arrow shows the periductal lymphocytic infiltrate. Note the presence of numerous intact salivary acini and the absence of fibrosis. Original magnification is $200 \times$. 


\section{Table 1}

Clinical and serologic findings that distinguishing SS from BMS

\begin{tabular}{|c|c|c|}
\hline Clinical Features & SS & BMS \\
\hline Autoantibodies & Anti-Ro, -La, -RF, -ANA & Absent \\
\hline Stomatodynia & Uncommon, may be due to fungal infection & Persistent, commonly localized to tongue \\
\hline Taste Disturbances & Absent & Characterized by persistent taste disturbances, metallic or bitter taste \\
\hline Xerostomia & Actual & Perceived \\
\hline Xerophthalmia & Actual & Absent \\
\hline
\end{tabular}

